\title{
The Politics of Water Payments and Stakeholder Participation in the Limpopo River Basin, Mozambique
}

\author{
Rossella Alba \\ Governance and Sustainability Lab, Trier University, Trier, Germany; alba@uni-trier.de
}

\section{Alex Bolding}

Water Resources Management group, Wageningen University, The Netherlands; alex.bolding@wur.nl

\author{
Raphaëlle Ducrot \\ CIRAD, Département Environnement et Sociétés, UMR G-EAU, Montpellier, France; and IWEGA, Faculdade de \\ Agronomia e Engenharia Florestal, Universidade Eduardo Mondlane, Maputo, Mozambique; \\ raphaele.ducrot@cirad.fr
}

\begin{abstract}
Drawing from the experience of the Limpopo River Basin in Mozambique, the paper analyses the articulation of a water rights framework in the context of decentralised river basin governance and IWRM-inspired reforms. The nexus between financial autonomy, service provision, stakeholder participation and the resultant allocation of water within the river basin is explored by scrutinising the newly instituted system of water permits and payments. Three cases are examined: (1) parastatal agencies managing large perimeters of irrigated land; (2) large-scale commercial companies irrigating land; and (3) so-called focal points representing groups of smallholder irrigators. The three presented cases show that structural challenges, local geographies and power relations shape the final outcome of water reforms in relation to decentralised river basin management, stakeholders' participation and accountability. Rather than improving accountability to users and securing the financial basis for sustainable infrastructure operation and maintenance, the permit system in place reinforces existing inequalities.
\end{abstract}

KEYWORDS: IWRM, policy articulation, elite, water permits, stakeholder participation, Mozambique

\section{INTRODUCTION}

Since the endorsement of the Water Act (GoM, 1991), the Mozambican water sector has experienced great transformations. Water reforms followed and partly anticipated the emergence of Integrated Water Resources Management (IWRM) as a dominant paradigm in the management of water resources (Mehta et al., 2014; Alba and Bolding, this issue). ${ }^{1}$ The river basin became the unit for water resources management substituting existing administrative divisions, followed by the decentralisation of decisionmaking to river basin authorities and creation of new arenas for stakeholder participation, the river basin committees (Inguane et al., 2014). Since the mid-1990s, 13 river basins have been defined following the watershed features: five Regional Water Administrations (ARAs, Administrações Regionais de Águas) were established while river basin committees ( $\mathrm{CB}$, Comité de Bacía) were introduced in

\footnotetext{
${ }^{1}$ For a discussion on the history and criticisms related to Integrated Water Resources Management and the conceptualisation of key elements of IWRM see the introduction to this issue. For insights about the introduction of IWRM policies in Mozambique, see Gallego-Ayala and Juizo (2011, 2012) and Inguane et al. (2014).
} 
most of the basins. Secondly, private forms of management and market-based policies were initiated, substituting for publicly managed entities.

Drawing from the experience of the Limpopo River Basin in Mozambique, this paper describes and analyses the challenges, opportunities and local innovations related with the introduction of formal water rights systems within the Mozambican part of the river basin. While the Mozambican articulation of IWRM-inspired reforms is analysed in another paper of this special issue (Alba and Bolding, this issue), here we concentrate on the introduction of water permits and payments for water within the Limpopo River Basin. We are particularly interested in the nexus between newly established forms of financial autonomy, service provision, stakeholder participation and the resultant allocation of water within the river basin.

In Mozambique, as in many other African countries, the introduction of a formal water rights framework (direito de uso e aproveitamento de água, in English: Right to use and exploit water) went hand in hand with the introduction of payments for abstracting water that (should) finance the provision of services from the Regional Water Administrations including the management of hydraulic infrastructure (e.g. dams). The basic mantra informing these new policies emphasises the beneficial effects of 'less State, more market and more users' involvement in water governance. The promise of such a move lies in substituting for lethargic, ineffective, cash-strapped public agencies with financially autonomous agencies supplying water in exchange for payment and downstream accountability. Through such a move one would shift accountability relations from predominantly upward accountability to the State treasury towards downward accountability and service provision for paying water users. Hence, in theory, the water agency becomes oriented not so much to the National Treasury but rather to the actual water users and the satisfaction of their needs in exchange for improved or even full cost recovery (see Small and Carruthers, 1991; for a critique, see Oorthuizen and Kloezen, 1995).

In theory, the newly introduced permit and payment system aims to achieve productive, equitable and sustainable use of scarce water resources. It hopes to do so by instituting a democratic and transparent mechanism of financial accountability and cost recovery. However, this paper will show that in the case of the Mozambican part of the Limpopo River Basin, the introduction of permits, water payments and participation in decision-making are not operating as envisaged in theory. Indeed, while large-scale water users secure their access to water by mobilising their resources (including political connections, licences and payments), small-scale users are largely ignored or are made to pay for water through the creation of so-called Focal Points, while not receiving vital services in return (see also van der Zaag et al., 2010). While IWRM as a policy concept provides the overall frame for scrutinising the interrelation between water payments and user participation in water governance, the paper does not aim to assess how well IWRM was implemented in Mozambique; neither does it aim to compare its implementation in Mozambique with IWRM implementation in other countries.

In the remainder of this paper we first explain the conceptual lens and applied methodology of the study, then present both the characteristics of the Mozambican part of Limpopo River Basin (water availability and use, main water users) and the key policy moves responsible for instituting a new water rights framework and its associated neo-liberal payment regime. Next we assess the new water allocation dispensation in practice by scrutinising how the Southern Region Water Administration (ARASul, Administração Regional de Águas do Sul) has been issuing water permits and collecting fees from users located in the Limpopo Basin including (1) parastatal agencies managing large perimeters of irrigated land; (2) large-scale commercial companies irrigating land; and (3) the so-called focal points representing groups of smallholder irrigators. In the subsequent conclusion and discussion we point at the flaws in the financial autonomy model and propose alternative ways of administering water use(r)s, that are more user friendly and likely to be more effective in the Mozambican circumstances. The principles of the proposed alternatives may be equally relevant in other African river basins. 


\section{CONCEPTUAL FRAMEWORK}

\section{Water permits and payments}

Permits refer to legal entitlements or formal authorisation issued by a state agency to a user, in the form of a licence or a concession formally recognising the user's right to abstract a certain amount of water during a certain period of time from a source. ${ }^{2}$ In theory, permits contribute to 'reserve' water for certain uses and make users' administratively visible as a licence formally recognises, not only the existence of a user but also her or his water requirements. Water permits introduce an administrative order mediating water and society, and in this way, they simplify the reality of the river basin and make it legible (Scott, 1998). The careful registration of permits offers an opportunity to account for the river discharge already committed and the water that remains available for future development/allocation within a river basin The underlying idea is that "a clear definition of who is entitled to use a certain amount of water, with the specification on when and where this is possible, will reduce uncertainty and conflicts" (Molle, 2004: 208). In neoliberal thinking, water permits are often regarded as a means for ensuring rational water use, helping to address water scarcity (Boelens and Zwarteveen, 2005).

Yet, holding a licence does not guarantee access to, and use of, water. In fact, legal permits are only one of the mechanisms of access to water resources (Ribot and Peluso, 2003). The authors also stress the importance of access to technology, capital, knowledge and authority. In the context of water rights, Boelens and Zwarteveen (2005) look at formal authorisation as one of the three dimensions constituting water rights and refer to technical infrastructure (i.e. dams, weirs gates, pumps, canal) and management tasks including decision-making processes and mobilisation of resources (i.e. money, social connections) as the other two. Furthermore, it is worth mentioning several issues that play a role in relation to allocation of water permits. First, power relations and the availability of economic resources influence users' ability to obtain a permit and access water. Large-scale and better-off users can make use of their wealth of resources to secure access to water at the expense of other, less powerful, and less wealthy users (Franco et al., 2013). Second, in southern Africa as well as in other regions, there is a dual legal framework, viz. (informal) customary law systems that acknowledge, protect and legitimise water use at community level and State-backed civic and statutory law systems that are administered at national level. Official water permit systems typically work at national level and often override or mix-up customary rights. Thirdly, the institution of formal legal frameworks for water rights allocation has often been tied together with the introduction of forms of water payments such as (volumetric) water pricing (Van Koppen, 2003). Payments for water come in the form of a tax or fee over the volume of (raw) water abstracted from the river by one user or multiple users for productive uses (e.g. agricultural, industrial, drinking purposes). Registration, coupled with taxation, results in discouraging smallholder registration and keeping them 'invisible' and their uses not accounted for (Veldwisch et al., 2013). The latter may present a 'dangerous' side-effect when water that is already beneficially used by informal, invisible downstream users gets (re)issued to legally recognised upstream water users in the form of new permits (van der Zaag et al., 2010). In the section below, we further conceptualise the relation between permits and payments for water by scrutinising the relationship between financial autonomy and accountability.

\footnotetext{
${ }^{2}$ In the case of Mozambique, two types of water permits exist: licence and concession. The main difference resides in the validity of the permit as the licence lasts for 5 years and then has to be renewed, while the concession lasts for 50 years (GoM, 1991). There is also a difference in application procedure, which reflects their order of magnitude - concessions being issued only in case of large abstractions (none were issued until the application by MAI in Massingir, described below in this paper).
} 


\section{Financial autonomy and accountability}

The drive for reforming public agencies into semi-private, financially autonomous agencies originated from the irrigation sector in the 1980s. In that decade the debt crisis, which started with the first oil crisis in the early 1970s, came to a head: many nations in the South that relied heavily on irrigated production started to suffer from shortages of funds to both operate and maintain publicly managed irrigation schemes (see Oorthuizen and Bolding, 2010). As a result, production in these systems declined, which in turn negatively affected both government revenues derived from export crops and the willingness of farmers to pay more for their systems' upkeep. Hence, many publicly managed irrigation schemes entered a vicious cycle of decline, where poor upkeep resulted in poor service delivery (unreliable water distribution) and poor yields, which in turn affected the willingness of farmers to pay (ibid). To break this cycle several neo-liberal and neo-institutional policy recipes were tried, like the introduction of volumetric water payments, which proved difficult to implement in largescale canal irrigation schemes (Repetto, 1986; Moore, 1989), and the transfer of irrigation management (also referred as IMT or Irrigation Management Transfer) to users through the establishment of Water User Associations and other forms of collective action (Wester, 2008; Ostrom, 1992). Drawing from the irrigation sector, we explain below how we conceptualise financial autonomy and how services, accountability and user participation are interlinked in theory.

Financial autonomy in the irrigation sector is defined as a condition where the water agency must rely on user fees for a significant portion of the resources used for operation and maintenance (O\&M) including staff salaries, with the agency exercising expenditure control over the use of the funds generated from these charges (Small, 1990). In theory, in an environment of financial autonomy, irrigation performance will improve, compared to publicly managed irrigation systems, by both freeing the O\&M budget from the constraints imposed by the central government's fiscal difficulties, and increasing the accountability of the irrigation system managers to the water users (Small and Carruthers, 1991).

Accountability is defined as the extent to which the performance of all managers and staff having responsibilities at different levels of an irrigation organisation is monitored and controlled by the water users (Uphoff et al., 1991). Financial autonomy improves the accountability of the agency to farmers, because it presumably transforms the position of farmers from mere water users into clients or consumers of services of the agency. Since the agency depends financially on fees collected from farmers, it has a clear stake in providing their clients with an efficient service (see Figure 1). In other words, following the popular reasoning which says that 'one should not bite the hand that feeds you', financially autonomous agencies are stimulated to be accountable to their clients who want to get their money's worth. Such an agency can be expected to increase the amount of effort they put into O\&M as it wishes to increase the farmers' capacity and willingness to pay fees. If fees are levied on an area basis, as is commonly done in the irrigation sector, this means that the agency has a strong vested interest in expanding the area receiving adequate irrigation service, increasing fee collection rates, and increasing farm incomes (Svendsen, 1993). Hence, financial autonomy provides strong incentives to the irrigation agency to improve the quality of its management of public systems.

Financial autonomy in theory also provides a strong incentive for cost-effective management. The agency's interest is to reduce costs to keep its budget in the black, while farmers like to keep the fees as low as possible. This mutual interest stimulates a greater efficiency in resource use and an economically rational division of tasks (Small and Carruthers, 1991). 
Figure 1. Diagram depicting the relations in terms of finance and accountability between central government, bureaucracy (e.g. Regional Water Administration) and farmers.

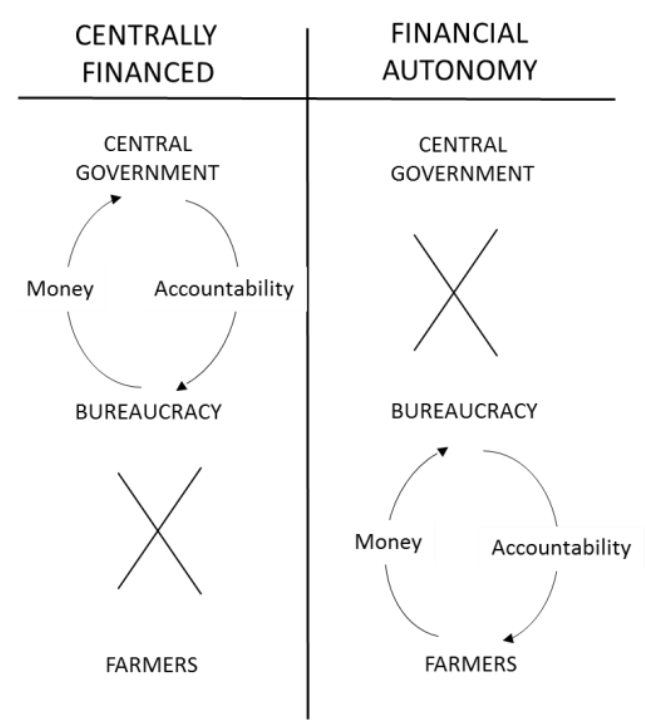

Source: Oorthuizen and Bolding (2010)

In itself, this 'money-based-farmer-empowerment-approach' is understandable and offers potential. However, increasing evidence shows that the beneficial effects of financial autonomy on State-water users relationships may not apply. In the Philippines the irrigation agency, the National Irrigation Administration (NIA), was reformed into a financially autonomous agency during the seventies. The results of this reform in terms of farmer empowerment and the quality of work of the irrigation bureaucracy are at best mixed. Oorthuizen (2003) has demonstrated that the reorientation of NIA from the central government financing to fee collection from farmers, seriously affected the performance of agency staff: they spent most of their time and effort on harassing farmers to pay their fees (which constituted a considerable part of their salaries) at the expense of actual water delivery or maintenance of the system. On the positive side, it is probably true that the withdrawal of State subsidies for irrigation management to NIA was one of the important contributing factors behind the 'transformation of the bureaucracy' into a more progressive and client-oriented agency (Bagadion, 1989). It stimulated the adoption of its widely praised participatory programme, in which farmers participate in construction activities as well as management. This indeed empowered farmers vis-à-vis the NIA in a few pilot areas (IIlo, 1989), and may have had a positive impact on the overall management performance of the agency-managed systems (Svendsen, 1993; NIA, 1994). On the other hand, it has been argued that the NIA's financial interests impeded the emergence of strong and viable farmer irrigators' organisations (Lauraya and Sala, 1994), and caused cuts in management expenditures which harmed the quality of irrigation management (Oorthuizen and Kloezen, 1995).

Attempts at improving irrigation management through the introduction of financial autonomy and accountability principles resonated with IWRM-inspired reforms dominating the water debate from the early 1990s onwards. Rather than the irrigation scheme, the river basin, the management of large-scale hydraulic infrastructure (in particular dams and weirs) and the presence of multiple users abstracting water directly from the river became the units of water rights reforms now aiming at improving water allocation between different uses and users while ensuring cost recovery. As van Koppen (2003) notes,

In the past, water rights were only well defined for localised systems such as irrigation systems, usually through a blend of customary and state law. Today, governments that declare themselves as the 
custodians of the nations' water resources are making the quantum jump from co-administering small schemes to regulating nothing less than the full hydrological cycle (pp. 1051).

New legal frameworks for water rights allocation based on permits and licences were introduced in several sub-Saharan African countries and tied together with forms of payments. The notion of water as an economic good and emphasis on stakeholder participation as promoted by the Dublin Principles, further contributed to the introduction of demand-driven approaches based on financial autonomy, cost-recovery and market principles (World Bank, 1993; Savenije and van der Zaag 2002; Molle and Berkoff, 2007). In the case illustrated in the paper, transposing the financial autonomy and accountability principles and mechanisms from the irrigation sector to water governance at river basin level ARA-Sul, as a financially autonomous institution, was supposed to maintain dams and supply water at the right place in the right amount at the right time, in exchange for a water fee that would cover its operating costs. Those water users that benefitted from water stored in infrastructure operated by ARA-Sul would pay for that water as soon as their water requirements exceeded that of uso comum (primary water use). However, how participation and decision-making come into this equation of financial accountability remains unclear, both in theory and in practice.

\section{MethodS}

This paper is based on a literature review, interviews and document analysis carried out in The Netherlands and Southern Mozambique between March and June 2013 (Alba, 2013). The research combined fieldwork research with an ethnographic method of engaging with policy actors called 'studying up' (Nader, 1972). The former included interviews and focus group discussions with representatives of large-scale users and smallholder ones abstracting water for agricultural use along Limpopo riverbanks. The latter, 'studying up', focused on the perspectives of the people who have influenced the policy process (i.e. the introduction of a legal framework for water rights) by setting the terms of reference and taking part in key events such as the drafting of the Water Act or the National Water Policies. Interviewees included senior and young engineers, consultants, lawyers, academics, staff of the National Water Directorate (DNA, Direç̧ão Nacional das Águas) and employees of ARA-Sul.

Altogether 34 interviews were carried out by the main author of the paper in English, Portuguese and the local Changana language (the latter with the help of a translator) and these were recorded as hand-written notes. In the case of smallholder users, interviews took place literally on their agricultural fields at their pump or intake points; in the case of large-scale users and policy-makers interviews were carried out in their offices in the city. Observations, analysis of the river basin cadastre (registry), and informal discussions during visits to the key hydraulic infrastructure in the Limpopo Basin (Massingir Dam, Macarretane weir and Chokwe intake) contributed to triangulate the findings. Extensive periods of fieldwork in the Limpopo River Basin and in the Pungwe River Basin of Mozambique by the two coauthors of the paper provided background information (e.g. Ducrot, 2011).

\section{THE CASE STUdY: MOZAMBIQUE AND LIMPOPO RIVER BASIN}

In Mozambique, the Water Act (1991) established a formal framework for the allocation of water rights based on licences and payments for the use of bulk water. The Law differentiates between usos comuns and usos privativos. The former refers to water uses for primary needs such as domestic use, watering of livestock and irrigation of crops for plots up to one hectare (ha) without the use of siphoning or mechanical instruments. The latter concerns bulk water use for industry, agriculture and energy production. While common uses are free of charge and do not involve a licence, private ones require a licence (or concession, here also referred to as a permit) and are subjected to the payment of a taxa de água, in English: water tax (GoM, 1991). Regional Water Administrations are responsible for registering users, issuing water licences and the collection of fees. These activities are carried out partly within the 
River Basin Management Units (in Portuguese, Unidades de Gestão de Bacía, UGB), which are decentralised offices of the ARAs.

The Limpopo River flows through Botswana, South Africa and Zimbabwe before reaching Mozambique. In Mozambique it covers a length of $450 \mathrm{~km}$ over the $1460 \mathrm{~km}$ full length of the river (Ducrot, 2011). The main tributary river is the Elephant River that runs through South Africa and then reaches the Limpopo River in Mozambique. The Massingir Dam represents the main infrastructure used to store water and protect the lower Limpopo valley from floods. A second infrastructural work, Macarretane Weir, is positioned downstream of the confluence between the Elephant and the Limpopo to provide water to the irrigation scheme of Chokwe. As van der Zaag et al. (2010) highlight, great uncertainties exist pertaining to the availably and use of water within the river basin. This is due to uncertainties surrounding future water development in upstream countries, incomplete discharge measurements and paucity of information on the water that is currently consumed particularly for agricultural production and domestic uses.

The river offers a key source of livelihood for the communities scattered along the riverbanks, as it is the main source of water for irrigation, drinking and domestic uses (including livestock watering) and the only permanent body of water in the basin. Within the Mozambican part of the basin, most of the users abstract water for agricultural purposes, cultivating an area between four and 30 ha (van der Zaag et al., 2010). According to UGBL (Unidade de Gestão de Bacía do Limpopo, Limpopo River Basin Management Unit, in English) in 2013 there were around 280 registered users together with an indefinite number of so-called 'common users', but these numbers are subjected to annual fluctuations (Alba, 2013). The river is a source of water for two main irrigation schemes, located in Chokwe and in downstream Xai-Xai, respectively. Both schemes are characterised by a long history that dates back to the 1950s when they were designed for use by Portuguese settlers (Veldwisch, 2015). Recently, largescale agro-industrial investments are emerging upstream of the Chokwe scheme (e.g. Agrisul, CAM). In 2011, the Mozambican government allocated about 37,000 ha of land directly downstream of Massingir Dam to MAI (Massingir Agro-Industrial) for sugar cane production that should start in 2017. When the project comes on steam, its projected water abstraction will have huge ramifications for water users downstream (van der Zaag et al., 2010).

Apart from the large water users, several smallholders and medium-size users populate the river basin. Since 2008, water users' groups, comprising mainly smallholder farmers, have been introduced into the river basin. Little information is available on the water users located along the main course of the Limpopo River flowing from Zimbabwe upstream of Macarretane weir. ARA-Sul has only started to register users in the areas of the basin where the flow of water is regularised by the presence of a dam (the Elephant River Basin downstream of Massingir) leaving out the areas that do not fall downstream of a dam (the main course of the Limpopo River upstream of the Macarretane Dam) as the irregularity of the water flow does not provide for them conditions to charge users. The Limpopo River also supplies drinking water needs for the two main cities in the basin, Chokwe and Xai-Xai.

Currently, water management follows a rather complex institutional framework where responsibilities are spread between several entities at regional, national and local levels. The scheme below shows the governance framework within the Mozambican part of the Limpopo River (Figure 2). At the regional level, SADC (Southern African Development Community) and LIMCOM (Limpopo Water Course Commission) play a role in influencing water management within the river basin. At the national level, the National Directorate of Water, within the Ministry of Public Works and Housing (MOPH, Ministério das Obras Públicas e Habitação), is responsible for overall water management and the implementation of the national water legislation and policies. ARA-Sul through its management unit (UGBL), manages water resources at the local level. UGBL is in charge of the management of the main infrastructure (dams and hydrometric and rainfall stations), the registration of water users, organisation of the cadastre and the collection of water fees. By managing the Massingir Dam and the Macarretane Weir, UGBL influences the quantity of water present in the river in relation to the water demand by the 
users. The Limpopo River Basin Committee (CBL, Comité da Bacía do Limpopo) serves as a consultative body for coordination between different users and institutions involved in land and water management in the river basin. At the time of the research, the Comite was composed mainly of representatives of district administrations and large- and medium-scale agricultural users. Smallholder farmers were not directly members of the CBL but are represented by members of irrigation associations (who are not smallholder farmers themselves; see Praagman, 2013). However, even though the Committee has been set up in the name of stakeholder participation, it rather works as an information dissemination body (Praagman, 2013). The committee has the official title of advisory body to the director of UGBL, thus leaving little role for stakeholders in terms of decision-making power at the river basin level.

Figure 2. Water management in Limpopo Basin.

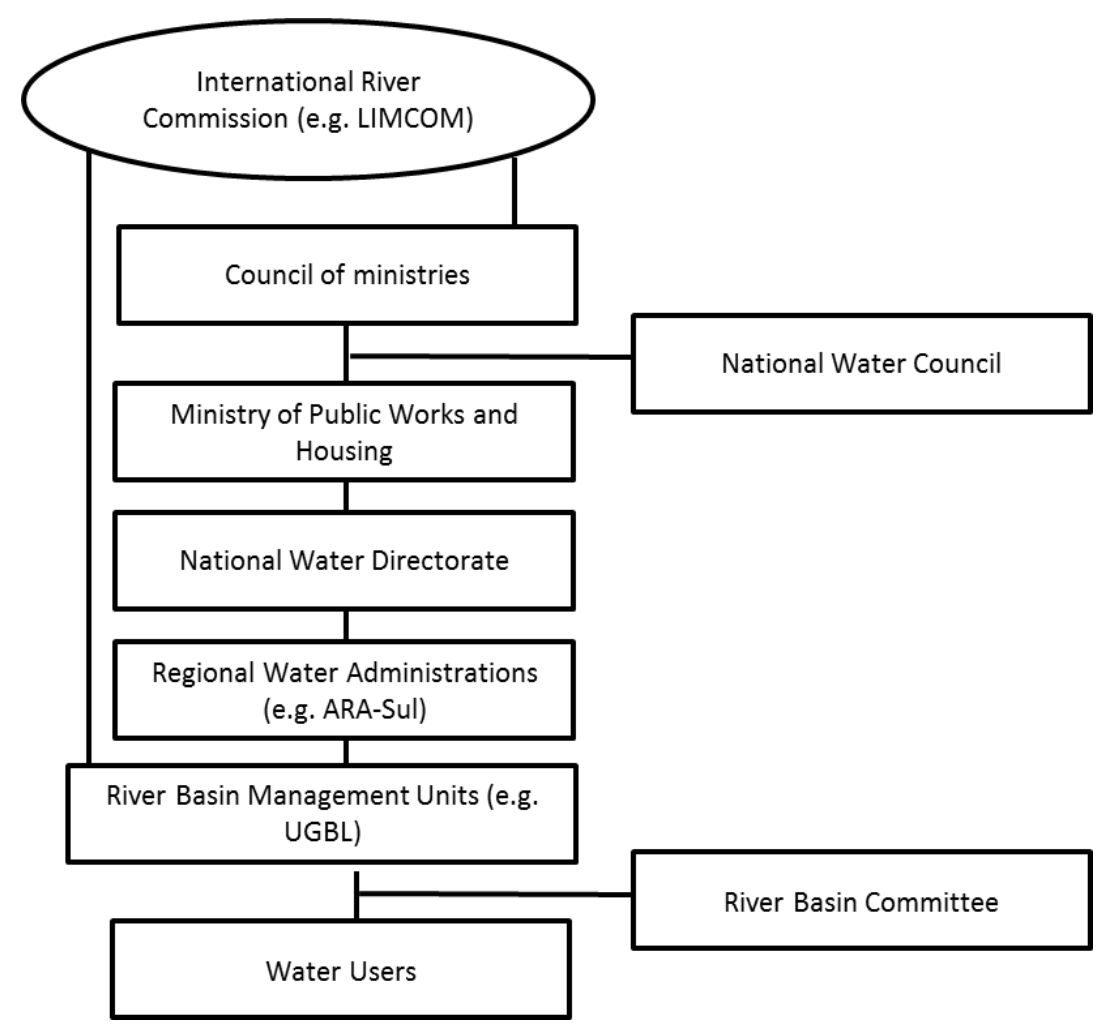

Source: own elaboration, based on Ducrot, 2011

\section{EXPERIMENTS WITH WATER PERMITS AND PAYMENTS}

Since the late Portuguese Colonial days, the Limpopo Basin together with the Incomati and Umbeluzi basins, the construction of hydraulic infrastructure in the Limpopo, Incomati and Umbeluzi river basins functioned as a catalyst for the management of water resources and the establishment of water-related administrations (Alba and Bolding, this issue). Harnessing the hydraulic potential for agricultural production through the development of dams, irrigation schemes and other infrastructure, was a key concern of both colonial and post-colonial governments (Alba, 2013). Furthermore, the Portuguese have left their imprint in the way irrigation schemes have been managed in the basin involving partnerships between the State and private capital.

As mentioned in the previous section, the 1991 Water Act is the reference framework for water permits in Mozambique. Although few data were collected in relation to the articulation of water permits (Alba, 2013), their early introduction can be explained in light of two aims: water demand 
control and cost-recovery. First, while water supply was increasingly regulated through the construction of hydraulic infrastructure, the actual water demand was subject to high degrees of uncertainty. Water permits were introduced as a way for accounting for the existing water demand at the river basin level. This is relevant given the downstream position of Mozambique and the increasing competition over water at the international level. Second, water permits provided the basis for introducing water charges at the river basin level. Indeed, holding a permit was introduced as a prerequisite for payment.

An early experiment with the introduction of volumetric tariffs took place in Umbeluzi and Limpopo river basins in 1988 when the Ministry of Public Construction and Water approved a tax for the 'beneficiaries' of bulk water from Pequenos Limbombos and Massingir dams (Solanes, 1989). According to Manjate (2010), bulk tariffs were introduced as a way to cover maintenance costs of the dams through the income generated from the tariffs paid by those benefitting from the use of the water stored in the dams. A similar rationality lies behind the introduction of water charges for abstracting water envisaged in the Water Act (1991). Indeed, as Alba and Bolding (this issue) further illustrate, water charges were introduced both as a cost-recovery mechanism and as a revenue generation exercise for the ARAs in light of the limited State finance to support new decentralised institutions. Cost-recovery represents also the guiding principle within the Water Tariff Policy (in Portuguese Politica Tarifaria de Aguas) that was approved by the Council of Ministers in 1998 (GoM, 1998). Yet, according to the policy, the same water charges are deemed suitable to promote pollution control, environmental protection and efficient use of water resources. According to the Water Tariff Policy, users should pay for the water they consume, applying the so-called user-pays principle. At the same time, tariffs should guarantee access to basic water needs for the whole population. The Policy uses the terms tarifa or taxa, which in general refers to water charges for bulk water abstraction or for service delivery. The tariff is set according to the costs of water resources management in each river basin (e.g. administrative costs, infrastructure maintenance costs). According to the Water Tariff Policy the water fees represent the revenue of the Regional Water Authorities.

During the 2000s, the operational decentralisation of water resources management and the financial autonomy of water authorities received great attention from the GoM and the ARAs themselves. Once all ARAs were formally established, the focus shifted towards improving their financial autonomy both from the central State and from the donors, supporting their establishment, by improving their ability to collect fees from water users. Yet, until 2010, the ARAs, excluding ARA-Sul, had remained largely financially dependent on grants received from the central administration (MOPH and DNA). Inguane (2010) suggests that this financial dependence interfered negatively with their decision-making autonomy as "most of the RWAs' plans are indirectly approved by the central level in regard to what they have to do with the central-allocated budget" (ibid: 60, RWA stands for ARA in this quote). Secondly, the central government has the last word over water fees as the Council of Ministry, based on a proposal by the Regional Water Administration, approves the level of the fees. In this way, the central government maintains control over the setting of the water fees, limiting the decision-making power of the ARAs. This tension between financial autonomy and State decision-making was confirmed during interviews (Alba, 2013).

In order to improve fee collection, several measures were taken by ARA-Sul. In 2004, a Business Plan was drafted to improve the financial autonomy of ARA-Sul (GoM, 2004). The Business Plan refers to 'venda de agua bruta' (in English, the sale of bulk water) and the concession of licences for water abstraction as one of the main ways to guarantee financial sustainability of the ARA and promote rational use of water (ibid: 3). In 2007, the commercial department of ARA-Sul was created and new bulk water tariffs were introduced for the southern region (Alba, 2013). The new tariff varies in each river basin within ARA-Sul depending on the cost for maintaining infrastructure and operational units. It also varies according to the use of water (e.g. agriculture, industry and drinking water). Since the approval of the bulk water tariff and the introduction of a regulation for licences and concessions, registration and fee collection have constituted two key activities of the local water administrations. 


\section{POST-2007 WATER ALLOCATION IN LIMPOPO - THREE CASES}

The Water Act of 1991 together with the Water Tariff Policy and the Regulations on Water Licences and Concessions (Regulamento de Licenças e Concessões), which were approved in October 2007, set the framework for water rights in Mozambique (GoM 2007a, 2007b). We highlight below how this regulatory framework has been articulated on the ground, drawing from three cases of fee collection in the Limpopo River Basin, each representing a different kind of user (parastatal, private companies, and smallholder irrigators). The data for these case studies were collected in 2008-2009 and 2013.

\section{State versus State: Chokwe and Baixo-Limpopo irrigation schemes}

In the Limpopo River Basin there are a few big water users. The two biggest are State enterprises under the Ministry of Agriculture: Hidráulica de Chokwe - Empresa Publica (HICEP) managing the Chokwe Irrigation Scheme and the Regadio de Baixo Limpopo - Empresa Pública (RBL-EP) managing the irrigation perimeter near Xai-Xai before the river discharges into the Indian Ocean. Due to their political importance and their linkages with the central government, these enterprises enjoy a special regime with regard to water licensing and fee collection. Both these enterprises are represented in the River Basin Committee.

HICEP was created in 1997 to manage the Chokwe Irrigation Scheme. With its 22,000 ha command area it is the largest and oldest irrigated perimeter in Mozambique offering space to commercial farming enterprises as well as smallholder and medium farmers (Pellizzoli, 2010). In 2012, nearly 12,000 farmers were occupying the scheme (Chilundo et al., 2012). However, in 2010 only 9400 ha were actually irrigated (van der Zaag et al., 2010) and during the hot season of 2011/2012 the area cultivated amounted to a mere 5781 ha (Chilundo et al., 2012). Since Independence, agricultural production in the Chokwe scheme has been decreasing together with the actual irrigated area (Veldwisch, 2015). The poor status of the infrastructure, salinisation, limited access to inputs (e.g. seeds and fertiliser), unreliable access to markets (few buyers, long distance) and lack of processing facilities represent some factors underlining the poor performance of the scheme (Veldwisch et al., 2013).

From the perspective of the UGBL, the scheme represents only one large-scale user that abstracts water from one single intake. From the intake at Macarretane, the water flows through the whole irrigation scheme and part of it returns to the river through the drainage system (Alba, 2013). Once a month, UGBL and HICEP staff meet at the intake and measure the water flow. Every three months an invoice is issued to HICEP based on the average measured water flow in the three previous months discounted by $40 \%$ (ibid). This arrangement has been introduced in order to facilitate the payment of the water charges by HICEP. Water requirements for the irrigation scheme for the whole year and the payment terms for the water charges are defined by HICEP and ARA-Sul/UGBL annually in a memorandum of understanding.

It is not clear if HICEP has ever paid for water. During interviews, several explanations for the inability of HICEP to pay were discussed (Alba, 2013). The most common explanation claims that the irrigation scheme does not 'use' the whole amount of water it takes. Due to the design of the infrastructure (gravity-led canals) a rather large amount of water is required to reach the last sector of the scheme ( $80 \mathrm{~km}$ away from the intake). However, not all that water is used for productive use, as the actually irrigated area covers less than 6000 ha. HICEP collects water fees only for the cultivated area, but it is charged by ARA-Sul for the total volume flowing through the main intake. Thus, HICEP is not able to pay ARA-Sul. Other interviewees referred to the unlikelihood that the State pays to the State. Indeed, HICEP is a State enterprise and UGBL/ARA-Sul are part of the State administration. However, the HICEP budget depends on the Ministry of Agriculture, while UGBL/ARA-Sul comes under the authority of the Ministry of Construction and Housing. Given the huge debt of HICEP towards ARA-Sul, since 2002 negotiations are taking place at ministerial level in order to find ways to settle the debt 
(GoM, 2004). By September 2008, the treasurer of HICEP admitted that they had incurred arrears on the ARA-Sul water bill to the tune of the equivalent of USD 2 million. ${ }^{3}$

The second state enterprise, RBL-EP, administers an area of 70,000 ha in the lower Limpopo including the Xai-Xai Irrigation Scheme. The scheme originally covered only an area of 12,000 ha. However, only part of the 70,000 ha is equipped with irrigation infrastructure (Ganho, 2013). Since 2005 a Chinese investor has been present in the perimeter (Praagman, 2013). As in the case of Chokwe, RBL-EP represents one user for the UGBL. As of June 2013, RBL-EP did not yet have a water licence. A memorandum concerning the volume of water abstracted as well as water charges, was under discussion between RBL-EP and UGBL/ARA-Sul.

\section{Private sector versus the State: Procana and Massingir Agro-Industrial (MAI)}

Starting in October 2007, ProCana, a subsidiary of a Cobalt mining company (CAMEC), announced its plans to irrigate up to 30,000 ha of land downstream of Massingir Dam. Sugar cane would be irrigated to produce ethanol in one of the biggest plants for biofuel production in Africa. ProCana was a joint venture owned by a London Stock Exchange (AIM) registered company called BioEnergy Africa Ltd (94\%) and a locally owned Mozambican company called Biolimpopo limitada (in which the then President, Guebuza, was rumoured to have a stake). To reassure its shareholders ProCana managed to acquire a temporary water licence, directly through the President's office, to the tune of 750 million $\mathrm{m}^{3}$ of water per annum. ${ }^{4}$ Whilst the recently upgraded Massingir Dam Reservoir had a storage capacity of approximately 2800 million $\mathrm{m}^{3}$, the reliable annual discharge of the Elephants River downstream of the dam was estimated at a maximum of 800 million $\mathrm{m}^{3}$ (see van der Zaag et al., 2010). The dam was further extended in 2014. At ARA-Sul senior staff were disgruntled by the issue of this huge water licence, committing 94\% of the annual flow to ProCana to the possible detrimental expense of other downstream users, such as HICEP and RBL-EP. Besides this neglect of downstream interests, ARA-Sul's main concern was that it had been bypassed in the decision to allocate the water, possibly for reasons of superior political expediency. ${ }^{5}$ This negative impact would only be partially mitigated by the promised 7000 jobs on the ProCana estate and the 10,624 ha of irrigated cane land under smallholder outgrower contract. ${ }^{6}$

However, in the end a number of adverse factors were responsible for the ultimate demise of ProCana and its grand plans for establishing a huge irrigated estate downstream of the Massingir Dam. First and foremost amongst these factors were not the domestic concerns of smallholder farmers who had been displaced by the newly established Limpopo National Park (whose new land for resettlement coincided with the land allocated to ProCana; see Milgroom, 2012) or the concerns of the smallholder irrigators of Marringuele Association, whose pump house and water licence had been taken over by ProCana to supply 125 ha of formerly smallholder land with water for a cane nursery (Manjate et al., 2010). After incurring losses to the tune of USD 7.7 million, reported on 29 September 2009, ${ }^{7}$ a radical change of strategy was announced by the Company on 6 October 2009. The main reason cited was "the

\footnotetext{
${ }^{3}$ Interview at HICEP, Chokwe, by Alex Bolding and others, 10 September 2008.

${ }^{4}$ AIM statement by BioEnergy Africa Ltd., entitled 'Admission to AIM', dated 1 September 2008, downloaded on 2 May 2009 from www.bioenergyafrica-Itd.com.

${ }^{5}$ Interview at ARA-Sul offices with senior staff, Maputo, by Alex Bolding and others, 12 September 2008.

${ }^{6}$ The figure of 7000 jobs kept being mentioned by both the Company itself and Mozambican and international media reports, despite the admission by the ProCana director that a maximum of 2000, mostly temporary, jobs would be created in case the Company opted for the subsoil drip system with mechanised combine harvesting of cane. Interview with country director of ProCana by Alex Bolding, Maputo, 22 September 2008.

${ }^{7}$ AIM statement by BioEnergy Africa Ltd, entitled 'Final statement for the 23-month period ended 31 March 2009', dated 29 September 2009, downloaded on 8 November 2009 from www.bioenergyafrica-ltd.com.
} 
global economic climate and current reduced interest in non-carbon related fuel products" which would make it "difficult for the Company to raise the necessary financing required under the Massingir Investment Agreement". ${ }^{8}$ So basically the global financial crisis, which especially hit the hedge funds on which ProCana relied for its investment capital, and the prospect of reduced oil prices in the mid to long term, meant the Company could not raise the necessary finance for the agreed investment plan. As a result, the Mozambican government nullified the issued land concession (DUAT), pulling the plug on the project.

What also played a role in the ultimate decision of CAMEC CEOs to pull out of the Massingir project were two technical factors. Firstly, there were the frustrating and protracted negotiations with ARA-Sul staff about the proposed water intake, which ultimately proved inconclusive. The Company wanted to construct its own pumping station on top of the dam abutment, rendering ARA-Sul's water releases from the main dam valves dependent on ProCana's water abstraction (effectively making ProCana a head end user on whom all other downstream users would become dependent for their own water supply). The option ARA-Sul preferred involved a pumping station along the river, downstream of the dam, which however would increase running costs for the Company, since they would have to pump the water up to the irrigated command area which was situated at a higher elevation. ${ }^{9}$ Secondly, in May 2008 a terrible incident took place at the dam, whereby the main valves and discharge pipe were blown out, due to the raised water pressure caused by the heightened dam wall. This incident negatively affected the ability of ARA-Sul to operate the water releases from the dam.

With the exit of ProCana, Massingir Agro-Industrial (MAI), a joint venture of South African-BritishMozambican origin entered the scene. Since 2011, MAI has sought to relaunch the project for the production of sugar cane in Massingir District. ${ }^{10} \mathrm{MAl}$ is a joint venture consisting of Transvaal Suiker Beperk (TSB) a South African sugar company (51\%) and Limpopo Agro-Industrial Investment Company (SIAL, 49\%), a Mozambican company whose chairperson is a former Minister of Industry. ${ }^{11}$ MAI plans to cultivate sugar cane on irrigated land of 37,500 ha and reserve 1000 ha for food production for the benefit of the population living near the project area (Borras et al., 2011). ${ }^{12}$ At the time of the research, production was envisaged to start in 2016 (Praagman, 2013). ${ }^{13}$

In May 2013, MAI was in the process of obtaining a land right for 37,000 ha and a water concession. At the time of the fieldwork, negotiations with ARA-Sul around a memorandum of understanding were taking place in Maputo. According to several interviewees, the draft memorandum allowed MAI to abstract half of the water from Massingir Dam Reservoir and half from a pumping station downstream of the dam. Meters for calculation of the volume of water abstracted were seen at each intake; thus MAl assumed it would have to pay according to the volume of water abstracted. ${ }^{14}$ MAl operated initially much more cautiously than ProCana, having to deal with the latter's negative heritage of broken promises and accusations of land theft by a number of NGOs. ${ }^{15}$ The cautious strategy is

\footnotetext{
${ }^{8}$ AIM statement by BioEnergy Africa Ltd., entitled 'Proposed adoption of investing policy and change of name', dated 6 October 2009, downloaded on 8 November 2009 from www.bioenergyafrica-Itd.com

${ }^{9}$ Interview with resident engineer, ARA-Sul, by Alex Bolding, Massingir, 7 May 2009.

10 'ProCana bio-fuel project to be relaunched', 25 November 2011, source: www.esi-Africa.com/node/13887, consulted on 9 December 2011.

${ }^{11}$ http://allafrica.com/stories/201211120298.html [last visited 10/08/13]

${ }^{12}$ According to the project 23,000 ha will be cultivated directly by MAI, 12,000 ha will be developed by SIAL and 2500 ha will be cultivated by local communities under an outgrowing model.

${ }^{13}$ In July 2016 the project was at a standstill (email communication, R. Ducrot, 10.08.2016).

${ }^{14}$ Interview with representatives of MAI by Rossella Alba, May 2013, Maputo, Mozambique (Alba, 2013).

${ }^{15}$ Interview with project manager MAl by Rossella Alba, 14 May 2013, Maputo. The negative accusations by NGOs are reported in Manual and Salomao (2009) and in an online article by Adam Welz, entitled 'Ethanol's African Land Grab',
} 
reflected in MAl's request for a water concession (rather than a licence) which has to be approved both by ARA-Sul and the Council of Ministers thus ensuring political goodwill and avoiding a loss of face on the part of ARA-Sul staff. ${ }^{16}$ Second, a MAI representative went to present their investment plans and water abstraction plan to the Comité da Bacía (river basin committee). This was done not to gain permission from the congregated stakeholders over their water allocation, but rather to create goodwill by informing potentially affected water users in a responsible manner (Praagman, 2013). ${ }^{17}$

\section{Smallholders versus the State: Focal points}

Besides the few large-scale users and the parastatal agencies supplying water to a variety of users as described above, the Limpopo and Elephant rivers supply water to hundreds of small- and mediumscale irrigators who live along the riverbanks and directly abstract water from these rivers using private or community-owned pumps. Here we refer to smallholders as users (individual or collective) who cultivate less than 30 ha of irrigated land (often only 3-4 ha).

According to the staff working for UGBL, registration and fee collection are quite challenging in remote areas that are physically difficult to reach due to distance and bad conditions of the roads (Inguane, 2010) leading to increased transaction costs for both UGBL staff and users (e.g. transport costs and time required). According to several interviewees, the lack of a culture of payment for water within the river basin further complicates the process. In order to deal with these difficulties, between 2008 and 2009 informal groups of water users led by one Focal Point (FP, in Portuguese ponto focal) were created with the support of UGBL. Often, the Focal Point is the leader of the village or a wellknown and respected man (e.g. a farmer) appointed by the water users. Since 2009, 13 groups have been established in the area downstream of the Massingir Dam. The size of the group is variable as is the number of users, as illustrated in Table 2. Due to the difficulties in calculating the volume of water abstracted by these remote users, the water charges are calculated according to the area each user cultivates based on a study of water requirements carried out by ARA-Sul between 2004 and 2005.

The Focal Points facilitate the registration of users and the collection of water fees. In theory, they also improve communication and information exchange. Indeed, the Focal Point represents a connection link between UGBL and the users (see Figure 3). The Focal Point is in charge of carrying out an inventory of the amount of land that each user has planted and/or effectively cultivated in a specific area and communicates it to UGBL. On the basis of the data collected by the Focal Point, the Basin Authority calculates the water charges and issues an invoice. Then, the Focal Point is in charge of collecting the money from the users and hand it over to the Basin Authority (Alba, 2013).

Focal Points represent a network of water users that reach the community level and (should) facilitate information exchange with the river basin authority (Praagman, 2013). Yet, at the time of the research, they seemed to serve more as a means to collect water fees than as a means of disseminating or collecting information. Focal Points, and in general smallholder farmers, are not represented in the River Basin Committee and play only a limited role in decision-making. Hence their financial accountability is completely separated from any (political) decision-making power or even being informed about dam openings that are increasingly the cause for potentially devastating flash floods (that might sweep mobile pump sets away).

published in March 2009 at www.motherjones.com/environment/2009/03/ethanols-african-landgrab, consulted on 25 May 2009.

${ }^{16}$ Interview with senior ARA-Sul staff by Alex Bolding and Rossella Alba, 16 May 2013, Maputo.

${ }^{17}$ Apparently, in 2015, a Kuwaiti group claimed it was going to restart the Procana project and/or take over the MAI project. The relationship between both is unclear. It seems TSB is still willing to invest with MAI and was supposed to start at the end of 2015 (personal communication, R. Ducrot, 3 December 2015). 
Table 1. Water users' group in the Limpopo River Basin.

\begin{tabular}{llll}
\hline $\begin{array}{l}\text { Users' } \\
\text { group }\end{array}$ & District & $\begin{array}{l}\text { Number } \\
\text { of users }\end{array}$ & $\begin{array}{l}\text { Area } \\
\text { cultivated } \\
\text { (ha)* }\end{array}$ \\
\hline I & Massingir & 7 & 10 \\
II & Massingir & 2 & 6 \\
III & Massingir & 14 & 37 \\
IV & Massingir & 2 & 4 \\
V & Massingir & 2 & 1.5 \\
VI & Chokwe & 15 & 26 \\
VII & Chokwe & 6 & 6 \\
\hline
\end{tabular}

\begin{tabular}{llll}
\hline $\begin{array}{l}\text { Users' } \\
\text { group }\end{array}$ & District & $\begin{array}{l}\text { Number } \\
\text { of users }\end{array}$ & $\begin{array}{l}\text { Area } \\
\text { cultivated } \\
\text { (ha)* }\end{array}$ \\
\hline VIII & Chokwe & 2 & 2 \\
IX & Chokwe & 2 & 3 \\
X & Chokwe & 18 & 35.5 \\
XI & Guija & 40 & 117 \\
XII & Chibuto & 3 & 0 \\
XII & Xai-Xai & 0 & 0
\end{tabular}

Source: own elaboration based on cadastre 2012 of ARA-Sul

*the area cultivated refers to the last trimester 2012

Figure 3. The Focal Point System (our elaboration).

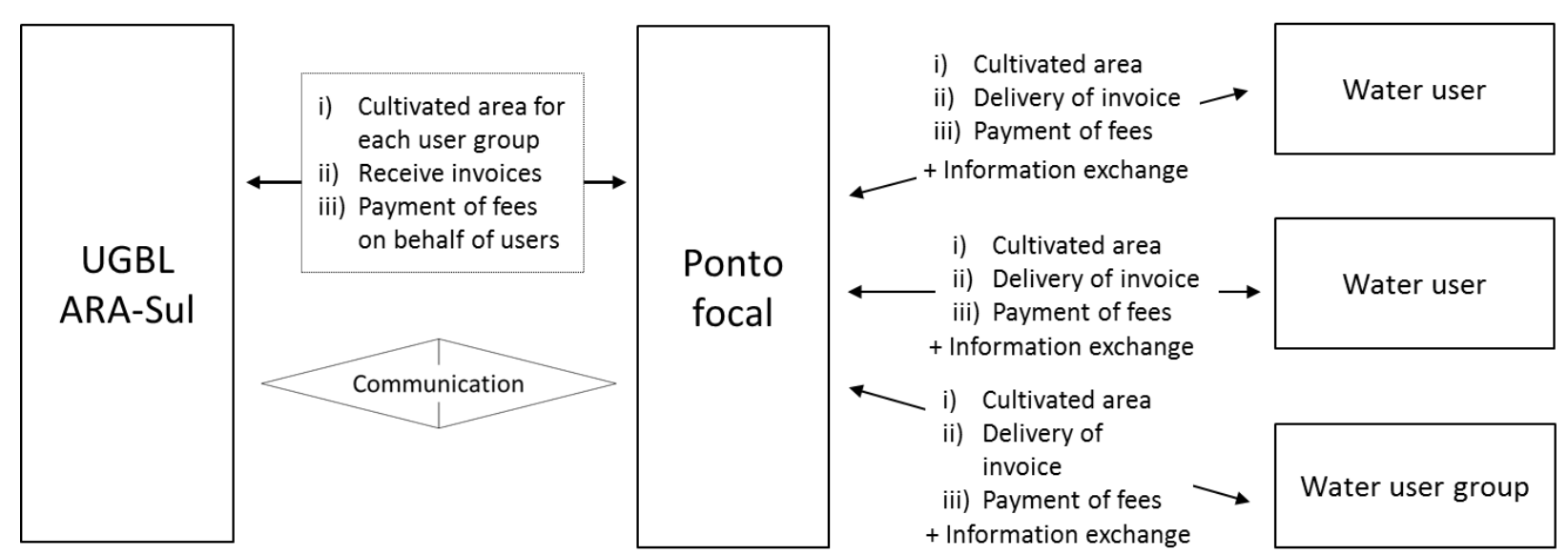

\section{ANALYSIS AND DISCUSSION}

The historical reconstruction of the articulation of the new water rights framework and the practices presented above and in Alba and Bolding (this Issue) foresee a key role for the central State and the decentralised ARAs in the definition of water rights (the policy), in the registration of users and in the role accorded to water users in accessing water and in decision-making about these practices. Yet, structural challenges and local geographies shape the final outcome of water reforms in relation to decentralised river basin management, stakeholders' participation and accountability. The examples given above portray several differences between water users that are not equal in terms or political connections, availability of financial resources, volume of water abstracted and also position in relation to the source. Equally, the capacity of Regional Water Authorities like ARA-Sul to administer and provide water to a multitude of water users is limited, certainly when taking into account the latter's different water requirements and various points of abstraction. We analyse below the outcomes of the newly instituted water payment and permit system by assessing for each of the four different user groups how political relations undermine the financial autonomy of ARA-Sul. Finally, we provide a 
number of pragmatic recommendations to achieve a modicum of financial sustainability and water user registration.

\section{Politics undercut the achievement of ARA's financial autonomy}

From the case material presented above, it is observed that ARA-Sul in its attempts to administer and supply water to the existing variety of water user groups has sought to reduce the number of transaction points, while aiming to secure a steady income through the introduction of a variety of different payment systems. On the other hand, various powerful water users have sought to acquire water rights and evade volumetric water payments through negotiations with authorities at a higher political level than ARA-Sul. Both trends have resulted in an active undermining of the financial autonomy of ARA-Sul.

Whereas the theory of financially autonomous agencies has it that agency services (volumes of water) are delivered in exchange for (user) payment, thus empowering water users and making the agency independent of State power, the practice as found in the Limpopo River Basin is different. Indeed, the hypothesis that sustains the reform, namely the creation of a client/service provider relation, does not hold given the politics of water allocation and the complexity of the river basin where a few large-scale users compete with a large number of invisible and dispersed small-scale users. The large-scale users are politically too sensitive to be sanctioned on the one hand, while the feasibility of charging dispersed users is problematic (in terms of cost-effectiveness). We examine below the position of each of the four groups of water users.

In the case of the two parastatal agencies (HICEP and RBL-EP) that administer and manage the formerly publicly managed irrigation schemes of Chokwe and Baixo Limpopo, ARA-Sul has taken the view that these represent one water user that can be charged for its water through a so-called memorandum that charges them for a fixed monthly water volume against a reduced rate. However, nonpayment of water bills has not resulted in suspension of the service provided by the Regional Water Authority: supply of water to the irrigation schemes. Hence, in the case of the Limpopo River, the financial accountability mechanism has been fatally undermined: the water authority lost the incentive of providing good services as it is not compensated for it by the users. In the case of the Limpopo River the reason for this must be sought in the large number of small- and medium-scale producers operating in these irrigated perimeters (whose production depends on the water) and their political importance. The Limpopo Valley can be regarded as the political heartland of the ruling Party FRELIMO (Pellizzoli, 2010). Moreover, it can be observed that the Ministry of Public Works, under which ARA-Sul operates, has failed to muster sufficient clout to exact payments from its sister Ministry of Agriculture for the services it provides to the latter. To some senior policy actors such intra-State payments may not make much sense.

Large-scale commercial water users like ProCana and MAI have secured huge water permits on the basis of political negotiations going beyond ARA-Sul's office. This way of securing water has undermined the principle of financial accountability between ARA-Sul and the Company (water user). Rather, the often personal and patrimonial interest of top policy actors (often located in the President's office) seems to override whatever relation exists between the service provider and the (foreign investment) company in question. The attempts of both ProCana and MAI to construct a pumping station on top of the Massingir Dam should be understood in the light of a desire on the part of the investment company to secure water for its estate at the expense of downstream interest in the same resource as well as securing independence from the service provider, ARA-Sul. Yet, as far as we could gather, both ProCana and MAI had to pay for the volume of water they abstracted from the river for their start-up operations. It remains unclear, however, what payments will be exacted once the full estate has been developed. 
Unable to collect sufficient money from large-scale users, regional water authorities have turned to smallholder farmers who operate downstream of water infrastructural works as a potential source of cost recovery. Water users' groups were established serving more as a means to register users and collect fees, rather than as a means to disseminate information. So-called Focal Points have been mobilised to act as tax farmers, exacting payment per unit of irrigated land from fellow irrigators. However, the absence of any kind of service provision in terms of information on water releases from dams or decision-making power through a seat on the Comite da Bacía, has threatened to undermine the financial accountability mechanism. Here it is the lack of political decision-making power on the part of the water users that negatively affects the achievement of financial autonomy for ARA-Sul. In this case, the conversion of Focal Points from cash into Power Points may be a necessary step for the policy of financial autonomy to work.

Finally, there is a large group of 'informal' water users, such as those smallholder farmers located in nonregulated areas of the Limpopo River and those depending for their livelihoods on machongos close to the river estuary, making use of their primary water right (uso comum), who escape registration and payment. By this very act they remain 'invisible' and their water use is unaccounted for, with the risk that the apparently 'unexploited' water is awarded to new large-scale investors (see also van der Zaag et al., 2010).

\section{Ways forward}

In terms of equitable resource allocation and sustainable water management, much can be gained by recognising the unequal position of water users in sociopolitical and economic terms and the difficulties that water authorities encounter in the licensing process. In the Limpopo River Basin, water users' groups and the Focal Points network offer the opportunity to involve small-scale users who cultivate their land outside large-scale irrigation schemes in decision-making and information exchange. Ensuring their representation in the River Basin Committee will contribute to fostering democratic practices in the management of water resources.

Recent developments in the river basin, such as agro-industrial investments (e.g. MAl) and new forms of agrarian change (see Ganho, 2013; Veldwisch, 2015), call for renewed attention for allocation of water resources (who gets the water and how) and the role of State actors. Further research on the practices related to access and allocation of water resources within Mozambican river basins is necessary. Besides the legal dimension involved with the water rights framework, technical and socioeconomic aspects should also be investigated (Boelens and Zwarteveen, 2005). These include the management and access to infrastructure and technologies that allow the users to physically access water and materialise their formal water rights, together with the ability of users to mobilise resources (e.g. money) and participate in decision-making processes.

With regard to previous attempts to cover the operating expenses of Regional Water Authorities like ARA-Sul, we would recommend to charge the large-scale water users for their water consumption, based on water measurements at the pumping station or main abstraction point, while avoiding payment by the multitude of small water users. The bulk of the water which is abstracted for productive purposes from any of the rivers in Mozambique, is used by relatively few large-scale water users, normally making up less than $10 \%$ of the total number of water users. Meanwhile, for those 'informal' smallholder water users who make use of their primary water right (uso comum) and make up the majority of water users, it could be better to reserve a dedicated amount of water based on demographic estimates, so as to prevent their water allocation being forfeited to large-scale users upstream. In this way, one can achieve both a form of financial accountability and a modicum of cost recovery without the presently prevailing inequities in both access and payment for water. 


\section{ACKNOWLEDGEMENTS}

The article draws on a research project funded by the Research Council of Norway - Flows and Practices: The Politics of Integrated Water Resource Management (IWRM) in Africa. A previous version of the paper was presented at the VI IESE conference, Maputo 26-27 August 2014. We would like to thank two internal reviewers (Emmanuel Manzungu and Barbara van Koppen) and three external reviewers for their constructive criticism.

\section{REFERENCES}

Alba, R. 2013. Travelling with IWRM: The articulation of water permits and payments for water in policies and practices in Limpopo river basin, Mozambique. MSc thesis. Wageningen University, Wageningen, The Netherlands.

Alba, R. and Bolding, A. 2016. IWRM avant la lettre? Four key episodes in the policy articulation of IWRM in the downstream nation of Mozambique. Water Alternatives, this Special Issue.

Bagadion, B.U. 1989. The evolution of the policy context: An historical overview. In Korten, F.F. and Siy, R. (Eds), Transforming a bureaucracy, the experience of the Philippine National Irrigation Administration, pp. 1-19. Quezon City: Ateneo de Manila University Press.

Boelens, R. and Zwarteveen, M. 2005. Prices and politics in Andean water reforms. Development and Change 36(4): 735-758.

Borras, Jr, S.M.; Fig, D. and Suárez, S.M. 2011. The politics of agrofuels and mega-land and water deals: Insights from the ProCana case, Mozambique. Review of African Political Economy 38(128): 215-234.

Chilundo, M.; Munguambe, P. and Namagina, C. 2012. Contextualização e Sintetização dos Estudos Realizados no Âmbito do Regadio de Chókwè, Relatório Final. Maputo: Faculdade de Agronomia e Engenharia Florestal, Universidade Eduardo Mondlane.

Ducrot, R. 2011. Land and water governance and pro-poor mechanisms in the Mozambican part of the Limpopo basin: Baseline study. Working Document, CGIAR (Consultative Group for International Agricultural Research) Challenge Programme on Water and Food. Maputo: IWEGA.

Franco, J.; Mehta, L. and Veldwisch, G.J. 2013. The global politics of water grabbing. Third World Quarterly 34(9): 1651-1675.

Gallego-Ayala, J. and Juízo, D. 2011. Strategic implementation of integrated water resources management in Mozambique: An A'WOT analysis. Physics and Chemistry of the Earth Parts A/B/C 36(14): 1103-1111.

Gallego-Ayala, J. and Juízo, D. 2012. Performance evaluation of River Basin Organizations to implement integrated water resources management using composite indexes. Physics and Chemistry of the Earth Parts $A / B / C 50-52$ : 205-216.

Ganho, A.S. 2013. 'Friendship' rice, business, or 'land-grabbing'? The Hubei-Gaza rice project in Xai-Xai. Working Paper No. 32. Sussex: Land Deal Politics Initiative (LDPI).

GoM (Government of Mozambique). 1991. Lei de Águas. Law n. 16/91 of August 3.

GoM. 1998. Political tarifária de Água (Water Tariff Policy). Resolution n. 60/98 of December 23.

GoM. 2004. Primeiro projecto nacional de desenvolvimento de água. Fundo Nórdico de Desenvolvimento: Crédito NDF 197. Business Plan da ARA-Sul, Fase II, Tomo 1: relatório principal. Unpublished Report.

GoM. 2007a. Política de Águas (Water Policy). Decree n. 46/2007, of October 30

GoM. 2007b. Regulamento de Licenças e Concessões de Águas (Regulations on Water Licenses and Concessions). Decree n. 43/2007, of October 30.

Illo, J.F.I. 1989. Farmers, engineers and organizers: The Taisan Project. In Korten, F.F. and Siy, R.Y. (Eds), Transforming a bureaucracy: The experience of the Philippine National Irrigation Administration, pp. 31-60. Connecticut: Kumarian Press.

Inguane, R. 2010. Political, institutional and economic factors constraining the performance of decentralized water management in Mozambique: From the major perspective of government water functions. MSc thesis. University of Queensland, Brisbane, Australia. 
Inguane, R.; Gallego-Ayala, J. and Juízo, D. 2014. Decentralized water resources management in Mozambique: Challenges of implementation at river basin level. Physics and Chemistry of the Earth Parts A/B/C 67-69: 214225.

Lauraya, F.M. and Sala, A.L.R. 1994. Alternative support systems to strengthen Irrigators' Associations in Bicol, the Philippines, after irrigation management turnover. Sri Lanka: International Water Management Institute.

Manjate, C. 2010. Analysis of water and related laws in Mozambique. In van der Zaag, P. (Ed), What role of law in promoting and protecting the productive use of water by small-holder farmers in Mozambique?, pp. 9-29. Water rights in informal economies (CP66). Delft, The Netherlands: CGIAR (Consultative Group for International Agricultural Research) Challenge Program on Water \& Food.

Manjate, C.; de Oliveira, E. and Sibia, O. 2010. Water rights in informal economies: The case of ASAMA, the Associação dos Agricultores de Marreguele. In van der Zaag, P. (Ed), What role of law in promoting and protecting the productive use of water by small-holder farmers in Mozambique?, pp. 71-88. Water rights in informal economies (CP66). Delft, The Netherlands: CGIAR (Consultative Group for International Agricultural Research) Challenge Program on Water \& Food.

Manual, L. and Salomao, A. 2009. Biofuel and land rights in Mozambique - The ProCana case. Haramata 54: 1719.

Mehta, L.; Alba, R.; Bolding, A.; Denby, K.; Derman, B.; Hove, T.; Manzungu E.; Movik S.; Prabhakaran P. and van Koppen, B. 2014. The politics of IWRM in Southern Africa. International Journal of Water Resources Development 30(3): 528-542.

Milgroom, J. 2012. Elephants of democracy: An unfolding process of resettlement in the Limpopo National Park. $\mathrm{PhD}$ thesis. Wageningen University, Wageningen, the Netherlands.

Molle, F. 2004. Defining water rights: By prescription or negotiation? Water Policy 6(3): 207-227.

Molle, F. and Berkoff, J. 2007. Water pricing in irrigation: Mapping the debate in the light of experience. In Molle, F. and Berkoff, J. (Eds), Irrigation water pricing: The gap between theory and practice, pp. 21-93. Comprehensive Assessment of Water Management in Agriculture. Wallingford, UK and Cambridge, MA: IWMI/CABI.

Moore, M. 1989. The fruits and fallacies of neo-liberalism: The case of irrigation policy. World Development 11(17): 1733-1750.

Nader, L. 1972. Up the anthropologist: Perspectives gained from studying up. Reinventing anthropology 1972: 284-311.

NIA (National Irrigation Administration). 1994. The impact of the participatory approach on the performance of National Irrigation Systems. NIA consul. Quezon City: National Irrigation Administration.

Oorthuizen, J. 2003. Water, works and wages: The everyday politics of irrigation management reform in the Philippines. New Delhi: Orient Longman.

Oorthuizen, J. and Bolding, A. 2010. State and irrigation. In Lecture notes from the Irrigation and Development course. MSc in International Land and Water Management, Wageningen University, Wageningen, the Netherlands.

Oorthuizen, J. and Kloezen, W.H. 1995. The other side of the coin: A case study of the impact of financial autonomy on irrigation management performance in the Philippines. Irrigation and Drainage Systems 9(1): 1537.

Ostrom, E. 1992. Crafting institutions for self-governing irrigation systems. San Francisco: Institute for Contemporary Studies Press.

Pellizzoli, R. 2010. 'Green revolution' for whom? Women's access to and use of land in the Mozambique Chókwè irrigation scheme. Review of African Political Economy 37(124): 213-220.

Praagman, E. 2013. The political arenas of water management in the Limpopo basin, Mozambique. Stakeholder participation at different policy levels. MSc thesis. Wageningen University, Wageningen, the Netherlands.

Repetto, R. 1986. Skimming the water: Rent-seeking and the performance of public irrigation systems. Research Paper No. 4. Washington: World Resource Institute.

Ribot, J.C. and Peluso, N.L. 2003. A theory of access. Rural Sociology 68(2): 153-181. 
Savenije, H.H. and van der Zaag, P. 2002. Water as an economic good and demand management paradigms with pitfalls. Water International 27(1): 98-104.

Scott, J.C. 1998. Seeing like a state: How certain schemes to improve the human condition have failed. Yale University Press.

Small, L. 1990. Irrigation service fees in Asia. Irrigation Management Network Paper 90/1e. London: Overseas Development Institute.

Small, L.E. and Carruthers, I. 1991. Farmer-financed irrigation: The economics of reform. Cambridge: Cambridge University Press.

Solanes, M. 1989. Report on a mission to Mozambique. New York, United Nations.

Svendsen, M. 1993. The impact of financial autonomy on irrigation system performance in the Philippines. World Development 21(6): 989-1005.

Uphoff, N.; Ramamurthy, P. and Steiner, R. 1991. Managing irrigation: Analyzing and improving the performance of bureaucracies. New Delhi, Newbury Park, London: Sage Publications.

van der Zaag, P. 2010. What role of law in promoting and protecting the productive uses of water by smallholder farmers in Mozambique? Water rights in informal economies (CP66). Delft, The Netherlands: CGIAR (Consultative Group for International Agricultural Research) Challenge Program on Water \& Food.

van der Zaag, P.; Juizo, D.; Vilanculos, A.; Bolding, A. and Post Uiterweer, N. 2010. Does the Limpopo river basin have sufficient water for massive irrigation development in the plains of Mozambique? Physics and Chemistry of the Earth 35(13-14): 832-837.

van Koppen, B. 2003. Water reform in Sub-Saharan Africa: What is the difference? Physics and Chemistry of the Earth, Parts A/B/C 28(20): 1047-1053.

Veldwisch, G.J.; Beekman, W. and Bolding, A. 2013. Smallholder irrigators, water rights and investments in agriculture: Three cases from rural Mozambique. Water Alternatives 6(1): 125-141.

Veldwisch, G.J. 2015. Contract farming and the reorganization of agricultural production within the Chókwè Irrigation System, Mozambique. The Journal of Peasant Studies 42(5): 1003-1028.

Wester, P. 2008. Shedding the waters: Institutional change and water control in the Lerma-Chapala Basin, Mexico. PhD thesis. Wageningen University, Wageningen, The Netherlands.

World Bank. 1993. Water resources management strategy. A World Bank policy paper. Washington, DC: World Bank.

THIS ARTICLE IS DISTRIBUted UNDER THE TERMS OF THE CREATIVE COMMONS ATtRIBUtION-NonCOMmerCIAL-SHAREALIKE LICENSE WHICH PERMITS ANY NON COMMERCIAL USE, DISTRIBUTION, AND REPRODUCTION IN ANY MEDIUM, PROVIDED THE ORIGINAL AUTHOR(S) AND SOURCE ARE CREDITED. SEE HTTP://CREATIVECOMMONS.ORG/LICENSES/BY-NC-SA/3.0/LEGALCODE 